\title{
Ultrastructural observations on the annual infection pattern of Bonamia sp. in flat oysters Tiostrea chilensis
}

\author{
P. M. Hine \\ Fisheries Research Centre, MAF Fisheries, PO Box 297, Wellington, New Zealand
}

\begin{abstract}
Ultrastructural observations were made on Bonamia sp. in the oyster Tiostrea chilensis (syn. T. lutaria) from summer (January) to winter (August), when Bonamia is abundant in oyster tissues. From January to April, large numbers of dense forms were produced by repeated growth and binary fission. By June many Bonamia had grown to larger forms intermediate between dense and plasmodial forms, while plasmodial forms predominated in July and August. A few small dense forms were also present in August. With growth the parasite became more irregular in shape, with more haplosporosomes and mitochondrial profiles, and development of large arrays of smooth endoplasmic reticulum and multi-vesiculate bodies in diplokaryotic plasmodia. Three phases of annual infection. were recognised. An incubation phase (September to November) was followed by a proliferation phase (December to May) during which dense forms proliferated and were shed, and a plasmodial phase (June to August). Excretion of lipoid bodies in April, and a drop in lipoid body numbers in June, coincided with the end of the proliferation phase. Dense forms re-appeared during the following plasmodial phase, and may survive through the incubation stage after necrosis of plasmodia at the end of August. Infection patterns in oyster haplosporidians are discussed.
\end{abstract}

\section{INTRODUCTION}

Small protists cannot be studied effectively by light microscopy (LM), as shown by uncertainties in the nature, inter-relationships and origins of 'microcell' diseases in North America (Katkansky et al. 1969, Farley et al. 1988). Subsequent ultrastructural description of Bonamia ostreae Pichot et al., 1979, and other 'microcells' (Farley et al. 1988), have clarified the difference between species. The identity and life-cycles of many protists have been determined using transmission electron microscopy (TEM), but life-cycles of haplosporodians that form spores remain thus far unknown. Attempts at exsporulation have had some success (Desportes \& Nashed 1983, Azevedo \& Corral 1989), but it is not known how or where exsporulation is naturally triggered.

The oyster haemocyte parasite Bonamia ostreae is also a haplosporidian, but paradoxically, although a spore stage is unknown (Pichot et al. 1979), it is readily transmissable (Grizel et al. 1988). Despite this, there have been no published studies on the TEM of $B$. ostreae development, only descriptions of some of the stages observed, particularly dense forms (Pichot et al.
1979, Balouet et al. 1983, Grizel 1985) and plasmodial forms (Brehélin et al. 1982). Another Bonamia sp., serologically distinct (Mialhe et al. 1988) from $B$. ostrea, is pathogenic in oysters Tiostrea chilensis (syn. T. Iutaria) in New Zealand. Although it has not been possible to attempt experimental transmission of Bonamia sp. the parasite is known from an LM study (Hine 1991) to have an annual pattern of infection, which may represent a life-cycle. Attempts to differentiate different stages at the LM level (Hine 1991) suffered the same limitations as the the other LM studies of microcells.

This study was carried out to determine ultrastructural changes in the Bonamia sp. population over time, to see if such changes, taken together with previously published data (Hine 1991), indicated an annual lifecycle. A tentative life-cycle, based on all known data, is suggested.

\section{MATERIALS AND METHODS}

Samples of 50 oysters Tiostrea chilensis were collected in mid-January 1987 (1/87), and mid-April (4/ 

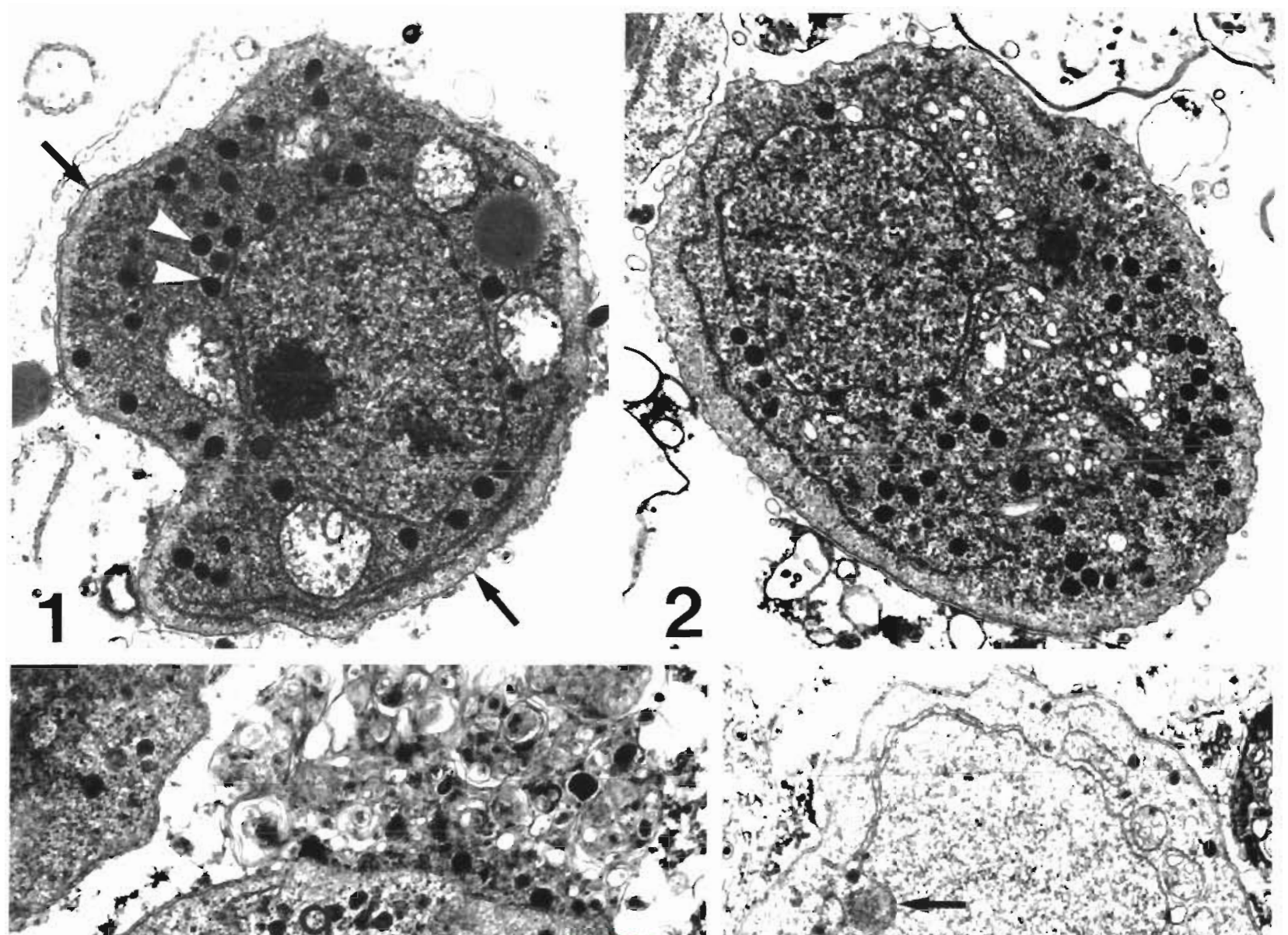

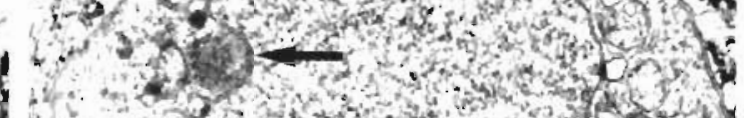

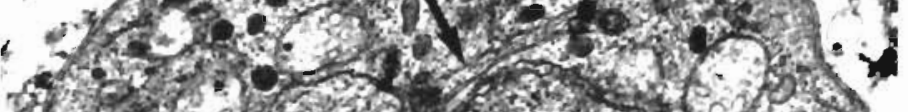

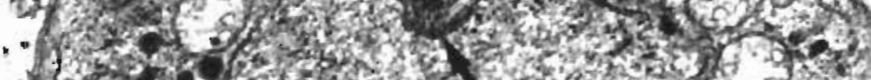

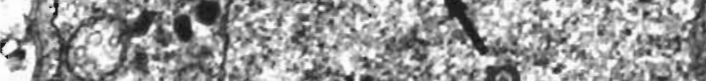

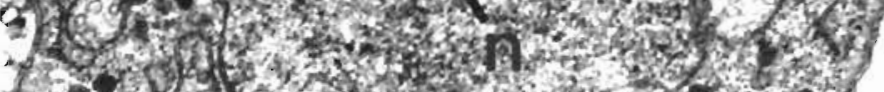

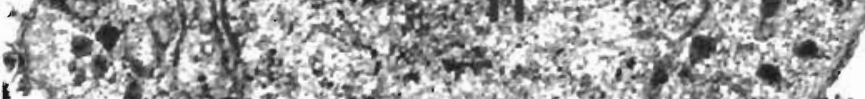

1.

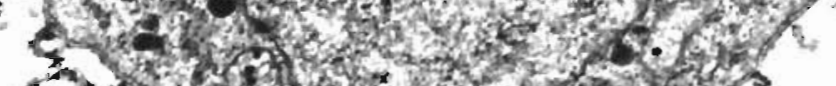

M.

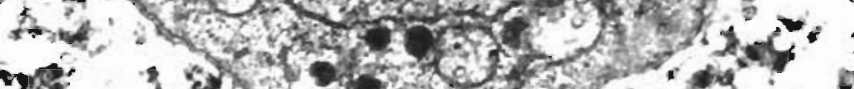

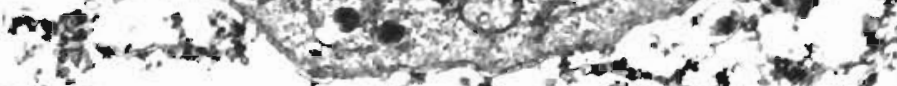

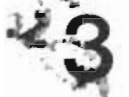

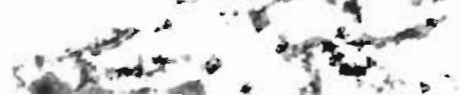

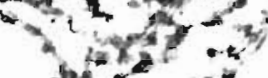

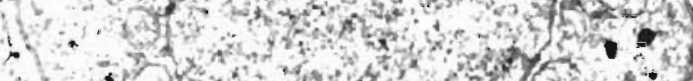

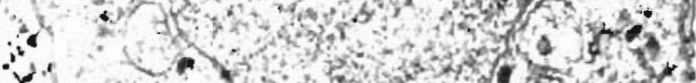

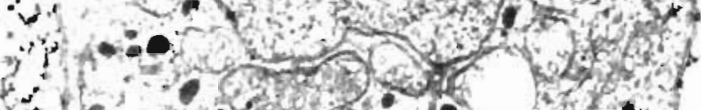

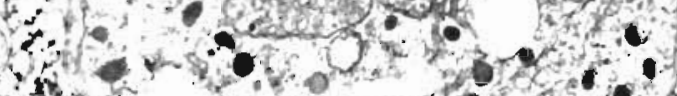

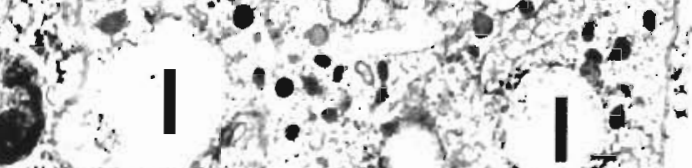

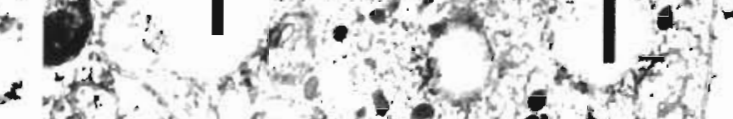

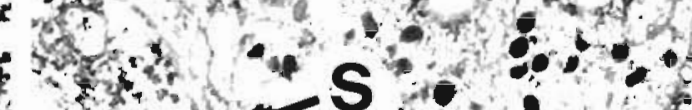

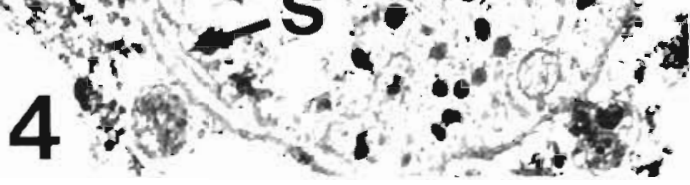

Figs 1 to 4 Bonama sp in Tiostrea chilensis Ftg. 1 Stage 1 dense form with characteristic haplosporosomes (white arrowheads) and clear margin devold of ribosomes (arrows) ( $\times 18$ 800). Fig. 2. Stage 2 developed dense form with more haplosporosomes than stage 1, but retaining a clear margin $(\times 18750)$. Fig. 3 . Stage 3 intermediate form, both the cell and nucleus are more irregular than earlier stages, and a nuclear material $(n) / G o l g i(g)$ complex is present $(\times 20000)$ Fig. 4 . Stage 4 developing intermediate form showing matenal in a nuclear indentation (arrow), developing arrays of peripheral SER (S), and lipoid bodies (I) ( $\times 16800)$ 


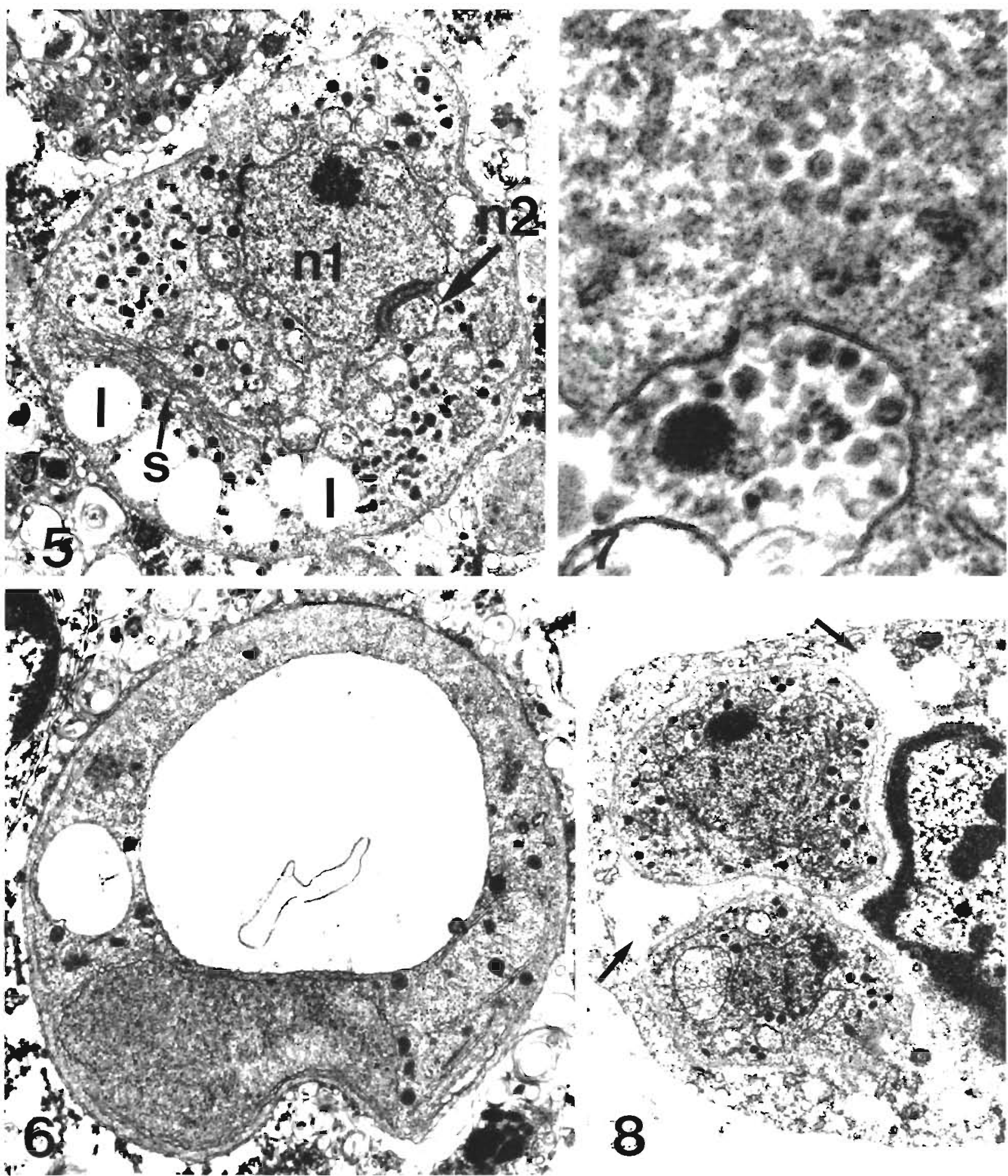

Figs. 5 to 8. Bonamia sp. in Tiostrea chulensis Fig 5. Stage 5 diplokaryotıc (n1, n2) plasmodium with lipold bodies (l) and welldeveloped peripheral SER (S) $(\times 15500)$ Fig. 6 Section through a vacuolated form $(\times 20250)$ Fig. 7 . Intra- and extra-cellular virus-like particles $(\times 111100)$. Fig. 8. Intracellular Bonamia with lipold droplets outside the parasite $($ arrowed) $(\times 11900)$ 
Table 1. Bonamia sp. Percent occurence of stages 1 to 5 over the sampling period. $\mathrm{n}=$ no. of parasites on which data are based

\begin{tabular}{|c|c|c|c|c|c|c|}
\hline & \multicolumn{6}{|c|}{ Month/year } \\
\hline & $1 / 87$ & $4 / 90$ & $6 / 90$ & $6-7 / 90$ & $7 / 90$ & $8 / 90$ \\
\hline $\mathrm{n}$ & 69 & 52 & 25 & 28 & 47 & 135 \\
\hline$\%$ stage 1 & 99 & 8 & 0 & 4 & 0 & 1 \\
\hline$\%$ stage 2 & 1 & 87 & 28 & 18 & 0 & 0 \\
\hline$\%$ stage 3 & 0 & 6 & 68 & 60 & 21 & 7 \\
\hline$\%$ stage 4 & 0 & 0 & 4 & 18 & 53 & 24 \\
\hline$\%$ stage 5 & 0 & 0 & 0 & 0 & 26 & 68 \\
\hline
\end{tabular}

90), mid-June (6/90), the end of June (6-7/90), mid-July (7/90) and mid-August (8/90) 1990, as Bonamia sp. is most abundant from January to August (Hine 1991). Oysters were opened one at a time by cutting the adductor muscle in the cupped valve, but leaving the oyster attached to the flat valve. The heart was removed and cut in two; one half was placed in TEM fixative and air-dried imprints were made of the other half. TEM-fixed tissues were cut into $<1 \mathrm{~mm}^{3}$ pieces. Tissues of $1 / 87$ oysters and replicate tissue of $4 / 90$ oysters were fixed in $2.5 \%$ glutaraldehyde in cacodylate buffer ( $\mathrm{pH} 7.2$ ), and replicate tissues of $4 / 90$ oysters and all subsequent samples were fixed in $2.5 \%$ glutaraldehyde in filtered $(0.22 \mu \mathrm{m})$ seawater. All tissues were fixed for 1 to $2 \mathrm{~h}$, and washed twice in buffer or seawater. Air-dried imprints were stained with the Merck Hemacolor system and examined to determine the presence and severity of infection.

After selection of heavily parasitised tissues, all tissues were post-fixed in $1 \% \mathrm{OsO}_{4}$ for $1 \mathrm{~h}$, stained en bloc with $5 \%$ uranyl acetate in $0.1 \mathrm{M}$ sodium acetate buffer for $45 \mathrm{~min}$, dehydrated in ascending 150 to
$100 \%$ ) ethyl alcohol, embedded in Araldite, sectioned, stained with $5 \%$ uranyl acetate for $10 \mathrm{~min}$ and $5 \%$ lead citrate for 5 to $6 \mathrm{~min}$, and examined on a Philips 420ST electron microscope.

\section{RESULTS}

Development was divided into 5 stages (Figs. 1 to 5 ), with stages 1,3 and 5 being designated dense, intermediate dense and plasmodial stages, respectively. The dense form was distinguished by its small size, few haplosporosomes and dense ribosomes, except around the cell periphery (Fig. 1). The intermediate stage was distinguished by its irregular cell and nucleus shape, and Golgi detached from the nucleus (Fig. 3). The plasmodial stage also had an irregular shaped cell and nucleus, but also contained multivesicular bodies (MVBs) (Perkins 1979), and large peripheral arrays of smooth endoplasmic reticulum (SER) (Fig. 5). Stages 2 and 4 were not clearly distinct, but were intermediate to the other stages.

Table 2. Bonamia sp. Quantitative changes in appearance over the sampling period. $\mathrm{n}=$ no. of parasites on which data are based

- Includes nuclear material in pit-like indentations of the nuclear surface, or near nucleus, MVBs, and Golgi with dense material between cisternae

\begin{tabular}{|c|c|c|c|c|c|c|}
\hline & \multicolumn{6}{|c|}{ Month/year } \\
\hline & $1 / 87$ & $4 / 90$ & $6 / 90$ & $6-7 / 90$ & $7 / 90$ & $8 / 90$ \\
\hline $\mathrm{n}$ & 106 & 61 & 26 & 34 & 49 & 147 \\
\hline Mean diameter ( $\mu m)$ & $3.1 \pm 0.4$ & $3.0 \pm 0.4$ & $3.1 \pm 0.5$ & $3.4 \pm 0.7$ & $3.8 \pm 0.5$ & $4.3 \pm 0.6$ \\
\hline$\%$ bi-nucleate & 9 & 7 & 0 & 0 & 2 & 5 \\
\hline$\%$ with intranuclear microtubules & 3 & 16 & 23 & 29 & 11 & 14 \\
\hline Mean no. mitochondria per section & $3 \pm 2$ & $4 \pm 2$ & $6 \pm 3$ & $6 \pm 3$ & $8 \pm 4$ & $9 \pm 4$ \\
\hline $\begin{array}{l}\text { Mean no. haplosporosomes } \\
\% \text { showing haplosporogenesis }\end{array}$ & $\begin{array}{c}15 \pm 7 \\
39\end{array}$ & $\begin{array}{c}21 \pm 9 \\
40\end{array}$ & $32 \pm 17$ & $30 \pm 13$ & $\begin{array}{c}44-25 \\
67\end{array}$ & $58 \pm 24$ \\
\hline$\%$ with lipoid granules & 44 & 56 & 23 & 62 & 51 & 73 \\
\hline Mean no. lipoid granules & $0.7 \pm 0.9$ & $1.1 \pm 1.5$ & $0.3 \pm 0.6$ & $1.4 \pm 1.4$ & $13 \pm 1.6$ & $2.1 \pm 2.0$ \\
\hline is intra-cellular & 35 & 49 & 81 & 96 & 94 & 88 \\
\hline$o_{0}$ extra-cellular & 65 & 51 & 19 & 4 & 6 & 12 \\
\hline
\end{tabular}


Between January and August, Bonamia sp. passed sequentially through developmental stages 1 to 5 (Table 1), with a few dense forms (stage 1) occurring in late June (6-7/90) and August. The parasite also grew, with decrease in density, and increase in the number of mitochondrial profiles and haplosporosomes (Table 2). Features connected with haplosporogenesis, such as indentations of the nuclear surface, extranuclear material, nuclear-bound Golgi, detached nuclear material/Golgi complexes, and Golgi cisternae containing dense material, increased over the period, except for a drop in June (Table 2). Stage 5 Bonamia were observed only in July and August samples. Stages with a dense plasma membrane and angular profile, or constricted into 2 halves, were seen only in July and August samples, and a vacuolated stage (Fig. 6) was seen only in August samples.

In January Bonamia sp. was usually extracellular, and many haemocytes were necrotic, but there was a subsequent increase in the proportion of parasites that were intracellular (Table 2). In July and August many degenerating Bonamia, some containing spherical to hexagonal virus-like particles of 36 to $38 \mathrm{~nm}$ diameter (Fig. 7), were phagocytosed by host haemocytes. Binucleate forms undergoing binary fission declined from January to April, and were not observed in subsequent samples, except for diplokaryotic stage 5 plasmodia in July and August samples. The presence of intranuclear microtubules increased to the end of June, and fluctuated thereafter (Table 2). The proportion of Bonamia with lipoid granules, and the mean number of granules per cell were similar over the period, except for a decline in June (Table 2), following the excretion of lipoid granules observed in $14 \%$ of Bonamia in April (Fig. 8).

\section{DISCUSSION}

Ultrastructural observations indicate that from January to August Bonamia sp. grew through the 5 developmental stages from dense forms in January to plasmodial forms in August, with reappearance of a few dense forms in late June and August. Results were similar to those of the LM study (Hine 1991), except that in the latter, plasmodial forms, as assessed by size and shape, peaked in April and August, whereas here, using MVBs as characteristic of plasmodia (Perkins 1979), they first appeared in July. Also at the LM level, Bonamia was mainly extracellular up to June, whereas here it was mainly intracellular in June. This may be due to restriction of observations here to heart haemocytes, whereas in the LM study all tissues were examined. The greatest difference was in the lower number of bi-nucleate stages seen here. This is prob- ably because, under the TEM, bi-nucleate cells appear uni-nucleate when only one nucleus is sectioned.

A tentative life-cycle is proposed on the basis of these and LM (Hine 1991) observations. Three phases are distinguished; an incubation phase (September to November); a proliferation phase (December to May); and a plasmodial phase (June to August).

\section{Incubation phase}

Oysters become infected by dense (stage 1) forms taken in during feeding, that burrow through the gut epithelium to usually lie under the gut basement membrane during the incubation phase. The dense forms are difficult to observe (Hine 1991) and correspond to the incubating subclinical 'late-summer' and fall Haplosporidium nelsoni (MSX) infections, and 8 to 10 mo of subclinical $H$. costalis infections, reported in Crassostrea virginica by Andrews (1982). There are also similarities to the life-cycle of Bonamia ostreae proposed by van Banning (1990), in the occurrence of an incubation period over winter and spring. However, for $B$. ostreae, the 'incubation' phase is synonymous with the 'developmental' phase and occurs in the ovary, and it is therefore equivalent to the proliferation phase described here. The dense forms probably derive from dense forms shed from the gonad, kidneys, digestive diverticulae, gills, gut, and dead oysters toward the end of the proliferation phase (April to May) (Hine 1991), when stage 2 Bonamia are frequently dividing by binary fission into stage 1 dense forms. Dense forms are found at the LM level from September onwards, and are also found in low numbers at the TEM level in August, when many necrotic Bonamia also appear very dense. Necrotic Bonamia could easily be distinguised by their degenerating organelles and irregular membranous whorls. Dense forms appear to remain inactive and undetected by the host, even when large intracellular stage 4 and 5 forms are being destroyed by the haemocytes.

\section{Proliferation phase}

This phase starts after the oysters spawn, predominantly as males, in December. The dense forms grow, become amoeboid, lose their basophilia, and divide by binary fission. Infected haemocytes become necrotic and lyse, and Bonamia sp. is therefore usually extracellular. Binary fission, proliferation and egress via the gonad, kidney, gut, gill and from decomposing oysters (Hine 1991) occur mainly when Bonamia are at stages 1 or 2. As parasite activation coincides with movement of parasite-infected haemocytes into the gonad to absorb 
unshed gametes, parasite activation may be triggered by endocrine changes in the host at or after spawning. The subsequent binary fission and proliferation of the parasite coincides with (1) an apparent inability of haemocytes to destroy the parasite, (2) decline in condition after female spawning, and (3) the availability of unspawned eggs as an energy reserve for Bonamia in the gonad.

The life-cycle described here differs from that of Bonamia ostreae proposed by van Banning (1990), as $B$. ostreae is thought to go through an ovarian phase prior to a haemocytic phase, but Bonamia sp. occurs in both the testis and the ovary, and is always closely associated with haemocytes.

It is during this phase that mortalities in the oyster beds are greatest. In Bonamia ostreae the dense form is the infective stage (Pichot et al. 1979, Grizel et al. 1988); it divides by binary fission (Balouet et al. 1983) and the parasite appears in oyster tissues 3 to $4 \mathrm{mo}$ after transmission (Tigé \& Grizel 1982). Therefore mortalities during the proliferation phase (December to May) are due to Bonamia from the incubating phase becoming activated and undergoing the rapid growth and division that characterises the proliferation phase. This pattern is similar to mortalities caused by Haplosporidium nelsoni in Crassostrea virginica in early summer due to 'late-summer' incubated infections and initial 'early-summer' infections 4 to 6 weeks after the incubation stage has ended (Andrews 1982).

Loss of haemocyte function may be related to increase in temperature over the summer (January to April). In Crassostrea virginica haemocyte function decreases during summer when temperatures rise (Fisher 1988, Fisher et al. 1989), and temperatures over the beds studied here vary by 7 to $8^{\circ} \mathrm{C}$ each year (Cranfield 1968). Parasite proliferation destroys haemocytes and haemocyte replacement draws on the energy reserves of the oysters, which are depleted by spawning, and the reserves in unspawned eggs may be utilised by the parasite, and unavailable to the oyster Similarly, Haplosporidium nelsoni (MSX) in Crassostrea virginica causes reduction in feeding (Newell 1985) and loss of fecundity and condition (Barber et al. 1988a), particularly lipid, glycogen and protein content (Barber et al. 1988b). The excretion of lipoid droplets by Bonamia sp. in April may be related to a change in energy reserves available to the parasite at that time.

\section{Plasmodial phase}

June samples differed from those of April in decreased haemocyte necrosis, the lack of bi-nucleated stages, and drop in both occurrence and number of lipoid granules. Stage 3 Bonamia sp. predominated in June, and the increase in bi-nucleate cells in July and August reflects the appearance of diplokaryotic plasmodia, unlike the bi-nucleate stage 1 and 2 cells seen in January and April. In July and August, most Bonamia, irrespective of stage, were dense and necrotic. A few had developed a darkened surface and angular profile similar to the sporonts of Minchinia dentale described by Desportes \& Nashed (1983), and plasmodia entering sporogony described in Haplosporidium costalis by Perkins (1969) and in Claustrosporidium gammari by Larsson (1987). Some were constricted, resembling the early stages of sporogony reported by Desportes \& Nashed (1983) in $M$. dentale and in $H$. comatulae by La Haye et al. (1984). In most other haplosporidians the plasmodial phase is followed by sporogony in the same host (Perkins 1968, 1969, 1971, 1975, van Banning 1977, Marchand \& Sprague 1979. Desportes \& Nashed 1983, Azevedo et al. 1985, Larsson 1987), and the angular and constricted forms may indicate early sporogony here.

Bonamia sp. is shed at stages 1 and 2 during the proliferation phase, which effectively ensures spread and survival of the pathogen. It then develops towards sporogony, but the host, and possibly viral infection, overwhelms the parasite before this can occur. Alternatively, it may be that sporogony occurs elsewhere in the oyster, or only occurs under adverse conditions to ensure survival of the parasite. However, spores have never been reported in $B$. ostreae, or observed in the many thousands of oysters examined during these studies. It is also unlikely sporogony takes place in another host, as sporogony occurs in the same host as plasmodia in most haplosporidians.

An alternative interpretation is that the Bonamia sp. studied here originally had alternating cycles of binary fission and sporogony, and sporogony may still occur under certain conditions. However binary fission of developed (stage 2) dense forms into (stage 1) dense forms is so effective in transmitting the parasite that sporogony is being, or has been, lost. Similarly, Mikrocytos mackini, the cause of Denman Island disease in Crassostrea gigas, does not have a known spore stage (Farley et al. 1988), but can readily be transmitted (Quayle 1961). On the basis of the widespread occurrence of dense forms (Pichot et al. 1979, Balouet et al. 1983, Grizel 1985), fewer reports of plasmodial forms (Brehélin et al. 1982) and no reports of sporogony in $B$. ostreae, it appears that $B$. ostreae may have lost the sporogonic phase altogether. Such a transition can be seen from Haplosporidium costalis, in which sporogony is well defined, to $H$. nelsoni, that seldom undergoes sporogony (Andrews 1982), and to Bonamia and Mikrocytos spp., which are readily transmitted without a spore stage. 


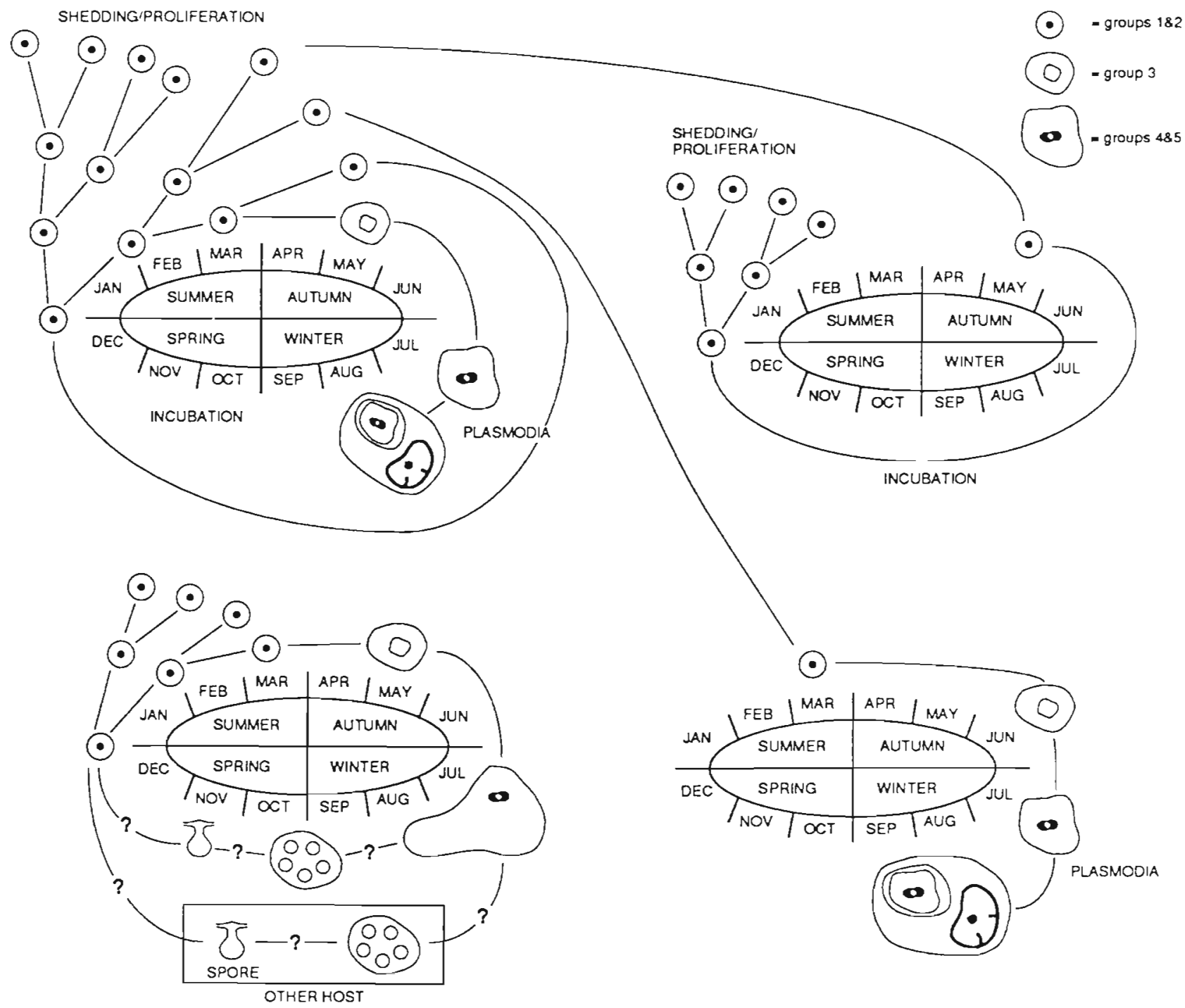

Fig. 9. Bonamia sp. Relationship of course of infection to time of infection. The annual cycle described in the text is shown at the top left. Bottom left shows the cycle if sporogony occurs elsewhere in the oyster or in an alternative host. If dense forms enter the oyster late in the proliferation phase (top right), they may incubate to proliferate the following December. If they infect earlier (bottom right) in the proliferation phase, they may develop on to the plasmodial phase

The course of bonamiasis may depend on the time of infection. In Fig. 9, the oyster at top left shows the annual cycle as described above, and the oyster at bottom left shows the possible life-cycle if Bonamia sp. undergoes sporogony elsewhere in the oyster or in an alternative host. If dense forms enter an uninfected oyster at the end of the proliferation phase, they may incubate as dense forms through to the following December (Fig. 9; top right). Rapid proliferation of a relatively heavy incubating infection may result in the death of the oyster in the following January to April. If an uninfected oyster becomes infected during the proliferation phase, Bonamia may enter the plasmodial phase but be present in insufficient numbers to resist being eradicated the following winter (July to August) (Fig. 9; bottom right).

In comparing Haplosporidium costalis and H. nelsoni in Crassostrea virginica, Andrews (1982) suggests $H$. costalis, with its short incubation, infection, sporulation and pathogenic stages, is a well-adapted native species. Conversely, H. nelsoni with its long infection periods, infrequent sporulation, intense pathogenicity and its appearance in Delaware Bay in 1957, may have been introduced by human movement of other oyster species (Andrews 1980). Bonamia sp. resembles $H$. nelsoni in its infection pattern, lack of sporulation, 
intense pathogenicity and apparent sudden appearance in 1986. However, the consistency of the annual infection pattern (Hine 1991) suggests it is a wellestablished parasite, and its effective transmission without known spores has negated the need for sporulation.

Acknowledgements. I am very grateful to Karen Reader of the Electron Microscope Facility, Victoria University of Wellington, for preparation of material for electron microscopy. I am also grateful to Janet Wain and Brett Wesney for their technical assistance.

\section{LITERATURE CITED}

Andrews, J. D. (1980). A review of introductions of exotic oysters and biological planning for new importations. Mar. Fish. Rev, 42 (Dec) 1-11

Andrews, J. D. (1982). Epizootiology of late summer and fall infections of oysters by Haplospondium nelsoni, and comparison to annual life cycle of Haplosporodium costalis, a typical haplosporidan. J. Shellfish Res. 2: 15-23

Azevedo, C., Corral, L. (1989). Fine structural observations on the natural spore excystment of Minchinia sp. (Haplosporida). Eur. J. Protistol. 24: 168-173

Azevedo, C., Corral, L., Perkins, F. O. (1985). Ultrastructural observations of spore excystment, plasmodial development and sporoblast formation in Haplosporidium lusitanicum (Haplosporida, Haplosporidiidae). Z. Parasitenkd. 71. 715-726

Balouet, G., Poder, M., Cahour, A. (1983). Haemocytic parasitosis: morphology and pathology of lesions in the French flat oyster, Ostrea edulis L. Aquaculture 34: 1-14

Barber, B. J., Ford, S. E., Haskin, H. H. (1988a). Effects of the parasite MSX (Haplosporidium nelsoni) on oyster (Crassostrea virginica) energy metabolism. I. Condition index and relative fecundity. J. Shellfish Res. 7: 25-3i

Barber, B. J., Ford, S. E., Haskin, H. H. (1988b). Effects of the parasite MSX (Haplosporidium nelsoni) on oyster (Crassostrea virginica) energy metabolism. II. Tissue biochemical composition. Comp. Biochem. Physiol. 91A: 603-608

Brehélin, M., Bonami, J.-R., Cousserans, F. Vivarès, C. P. (1982). Existence de formes plasmodiales vraies chez Bonamia ostreae parasite de l'huître plate Ostrea edulis. C. R. Acad. Sci. Paris, Série III, 295: 45-48

Cranfield, H. J. (1968). An unexploited population of oysters Ostrea lutaria Hutton, from Foveaux Strait. Part I. Adult stocks and spatfall distribution. N.Z. J. mar. Freshwat. Res 2: $3-22$

Desportes, I., Nashed, N. N. (1983). Ultrastructure of sporulation in Minchinia dentale (Arvy), an haplosporean parasite of Dentalium entale (Scaphopoda, Mollusca): taxonomic implications. Protistologica 19: 435-460

Farley, C. A., Wolf, P. H., Elston. R. A. (1988). A long-term study of 'microcell' disease in oysters with a description of a new genus, Mikrocytos (g.n.), and two new species, Mikrocytos mackini (sp.n.) and Mikrocytos roughleyi (sp.n.). Fish. Bull. U.S. 86: 581-593

Fisher, W S. (1988). Environmental influence on bivalve hemocyte function. In: Fisher, W. S. (ed.) Disease processes in marine bivalve molluscs. American Fisheries Society Special Publication 18, Bethesda, Maryland, p. $225-237$

Fisher, W S., Chintala, M. M., Moline, M. A. (1989). Annual variation of estuarine and oceanic oyster Crassostrea vir ginica Gmelin hemocyte capacity. J. exp. mar Biol. Ecol. $127 \cdot 105-120$

Grizel, H. (1985). Étude des récentes épizooties de l'huitres plate Ostrea edulis L. et de leur impact sur l'ostreiculture bretonne. Thèse de Doctorat, Université des Sciences Techniques du Languedoc, Montpellier

Grizel, H., Mialhe, E., Chagot, D., Boulo, V., Bachère, E. (1988). Bonamiasis: a model study of diseases in marine molluscs. In: Fisher, W. S. (ed.) Disease processes in marine bivalve molluscs. American Fisheries Society Special Publication 18, Bethesda, Maryland, p. 1-4

Hine, P. M. (1991). The annual pattern of infection by Bonamia sp. in New Zealand flat oysters, Tiostrea chilensis Aquaculture 93: 241-251

Katkansky, S. C., Dahlstrom, W. A., Warner, R. W. (1969) Observations on survival and growth of the European flat oyster, Ostrea edulis, in California. Calif. Fish and Game 55: $69-74$

La Haye, C. A., Holland, N. D., McLean, N. (1984). Electron microscopic study of Haplosporidium comatulae n. $\mathrm{sp}$. (Phylum Ascetospora: Class Stellatosporea), a haplosporidian endoparasite of an Australian crinoid, Oligometra serripinna (Phylum Echinodermata). Protistologica 20 $507-515$

Larsson, J. I. R. (1987). On Haplosporidium gammari, a parasite of the amphipod Rivulogammarus pulex, and its relationships with the Phylum Ascetosporea. J. Invertebr Pathol. 49: 159-169

Marchand, J., Sprague, V (1979). Ultrastructure de Minchinia cadomensis sp. n. (Haplosporida) parasite du décapode Rhithropanopeus harrisii tridentatus Maitland dans le Canal de Caen à la Mer. J. Protozool. 26: 179-185

Mialhe, E., Boulo, V., Elston, R., Hill, B., Hine, M., Montes, J. van Banning, P., Grizel, H. (1988). Serological analysis of Bonamia in Ostrea edulis and Tiostrea lutaria using polyclonal and monoclonal antibodies. Aquat. Living Resour. 1. $67-69$

Newell, R. I. E. (1985). Physiological effects of the MSX parasite Haplosporidium nelsoni (Haskin, Stauber \& Mackin) on the American oyster Crassostrea virginica (Gmelin). J. Shellfish. Res. 5: 91-95

Perkins, F. O. (1968). Fine structure of the oyster pathogen Minchinia nelsoni (Haplosporida, Haplosporidiidae). J. Invertebr. Pathol. 10:287-307

Perkins, F. O. (1969). Electron microscope studies of sporulation in the oyster pathogen, Minchinia costalis (Sporozoa: Haplosporida). J. Parasitol. 55: 897-920

Perkins, F. O. (1971). Sporulation in the trematode hyperparasite Urosporidium crescens de Turk, 1940 (Haplosporida: Haplosporidiidae) - an electron microscope study. J. Parasitol. 57. 9-23

Perkins, F. O. (1975). Fine structure of Minchinia sp. (Haplosporida) sporulation in the mud crab, Panopeus herbstii. Mar Fish. Rev. 37 (May-Jun): 46-60

Perkins, F. O. (1979). Cell structure of shellfish pathogens and hyperparasites in the genera Minchinia, Urosporidium, Haplosporidium, and Marteilia - taxonomic implications. Mar Fish. Rev. 41 (Jan--Feb): 25-37

Pichot, Y., Comps, M., Tigé, G., Grizel, H., Rabouin, M.-A. (1979). Recherches sur Bonamia ostreae gen. n., sp. n., parasite nouveau de l'huitre plate Ostrea edulis L. Rev. Trav. Inst. Pêches marit. 43: 131-140

Quayle, D. B. (1961) Denman Island oyster disease and mortality, 1960. Fish. Res. Bd Can. MS Rep Ser 713, p. 1-9

Tigé, G. Grizel, H. (1982). Essai de contamination d'Ostrea edulis Linné par Bonamia ostreae (Pichot et al., 1979) en 
Rivière de Crach (Morbihan). Rev. Trav. Inst. Pêches marit. 46: 307-314

van Banning, P. (1977). Minchinia armoricana sp. nov. (Haplosporida), a parasite of the European flat oyster. Ostrea edulis. J. Invertebr. Pathol. 30: 199-206

Responsible Subject Editor: W. Körting, Hannover, Germany van Banning, P. (1990). The life cycle of the oyster pathogen Bonamia ostreae with a presumptive phase in the ovarian tissue of the European flat oyster, Ostrea edulis. Aquaculture 84: 189-192

Manuscript first received: April 11, 1991 Revised version accepted: June 19, 1991 